\title{
Real-Time Continuous Nitrate Monitoring in Illinois in 2013
}

Many sources contribute to the nitrogen found in surface water in Illinois. Illinois is located in the most productive agricultural area in the country, and nitrogen fertilizer is commonly used to maximize corn production in this area. Additionally, septic/wastewater systems, industrial emissions, and lawn fertilizer are common sources of nitrogen in urban areas of Illinois. In agricultural areas, the use of fertilizer has increased grain production to meet the needs of a growing population, but also has resulted in increases in nitrogen concentrations in many streams and aquifers (Dubrovsky and others, 2010). The urban sources can increase nitrogen concentrations, too. The Federal limit for nitrate nitrogen in water that is safe to drink is 10 milligrams per liter (mg/L) (http://waterepa. gov/drink/contaminants/basicinformation/nitrate.cfm, accessed on May 24, 2013). In addition to the concern with nitrate nitrogen in drinking water, nitrogen, along with phosphorus, is an aquatic concern because it feeds the intensive growth of algae that are responsible for the hypoxic zone in the Gulf of Mexico. The largest nitrogen flux to the waters feeding the Gulf of Mexico is from Illinois (Alexander and others, 2008). Most studies of nitrogen in surface water and groundwater include samples for nitrate nitrogen collected weekly or monthly, but nitrate concentrations can change rapidly and these discrete samples may not capture rapid changes in nitrate concentrations that can affect human and aquatic health. Continuous monitoring for nitrate could inform scientists and water-resource managers of these changes and provide information on the transport of nitrate in surface water and groundwater.

\section{What is continuous and real-time nitrate monitoring?}

Continuous monitoring (collected every 15 minutes) for nitrate provides consecutive observations of nitrate concentration measured by a sensor placed directly in the body of water. Measurements are logged and stored by instrumentation at the field site. Real-time continuous nitrate data are first stored and then are transmitted to an offsite computer via satellite telemetry. The real-time data collected by the U.S. Geological Survey (USGS) in Illinois are uploaded from the computer to the Web site every hour (http://waterdata.usgs.gov/il/nwis/current/?type =quality\&group $\% 20$ Key $=$ basin $\% 20 c d$ ). The real-time transmission eliminates the waiting time inherent in laboratory chemical analyses and allows scientists and water managers to make decisions based on rapid changes in water quality.

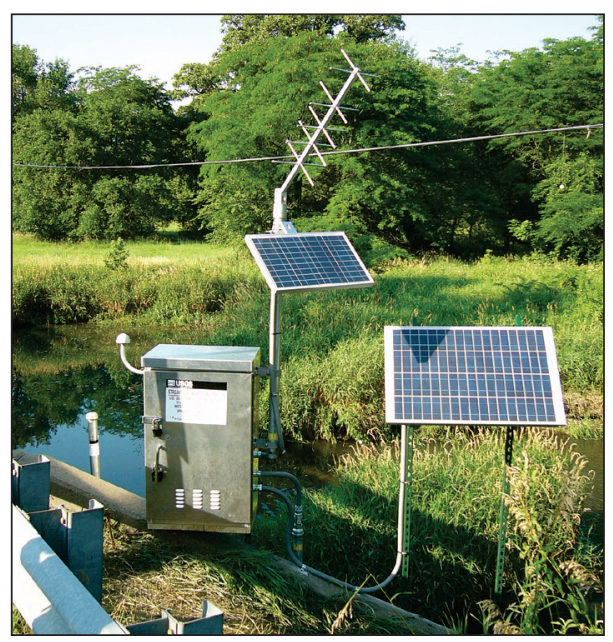

Instrumentation shelter and telemetry equipment are used for collecting, storing, and transmitting stream discharge and nitrate data at the U.S. Geological Survey (USGS) streamgage near Fairbury, Illinois (photo by Nicholas Siudyla, USGS)
A nitrate sensor operates on the principle that nitrate ions absorb ultraviolet (UV) light at wavelengths less than 220 nanometers (nm) (Pellerin and others, 2013). The sensor is designed to convert spectral absorption properties measured to a nitrate concentration by using laboratory calibrations and integrated algorithms to account for interferences from other absorbing ions and organic matter. This allows for realtime nitrate measurements without the need for chemical reagents. Suspended particles and highly colored water may affect the optical sensor, so consistently accounting for these factors is critical to the successful deployment and interpretation of results in different settings. The sensor has integrated or external antifouling systems, but the USGS typically has to clean and calibrate a nitrate sensor monthly, or as needed to remove sediment, biological growth, and lime scale.

\section{Where does the USGS measure nitrate continuously in Illinois?}

The USGS deploys continuous nitrate sensors in a variety of stream types, sizes, and locations in Illinois to better characterize the behavior and transport of nitrogen. In partnership with various cooperators and as part of the USGS WaterWatch program on streams from coast to coast (fig.1A), the USGS Illinois Water Science Center installed eleven nitrate sensors in multiple watersheds (Fox River, Indian Creek, East Bureau Creek, Spoon River, Kickapoo Creek (in Wabash River and upper Illinois River Basins), and Illinois River), (fig. 1B). These watersheds range in size from very small (3.8 square miles $\left.\left(\mathrm{mi}^{2}\right)\right)$ to very large $\left(26,870 \mathrm{mi}^{2}\right)$ (table 1).

The USGS is collecting and evaluating continuous nitrate data at a number of sites in the Midwest (fig. 1 A). Evaluation of the accuracy, effectiveness, and reliability of different types of nitrate sensors in the field is underway at two test sites in Illinois in coordination with the USGS Hydrologic Instrumentation Facility. For example, two continuous nitrate sensors have been installed on the Illinois River at Florence (previously called Illinois River at Valley City), which is the most downstream streamgage on the Illinois River Basin prior to discharge to the Mississippi (fig. 2). 


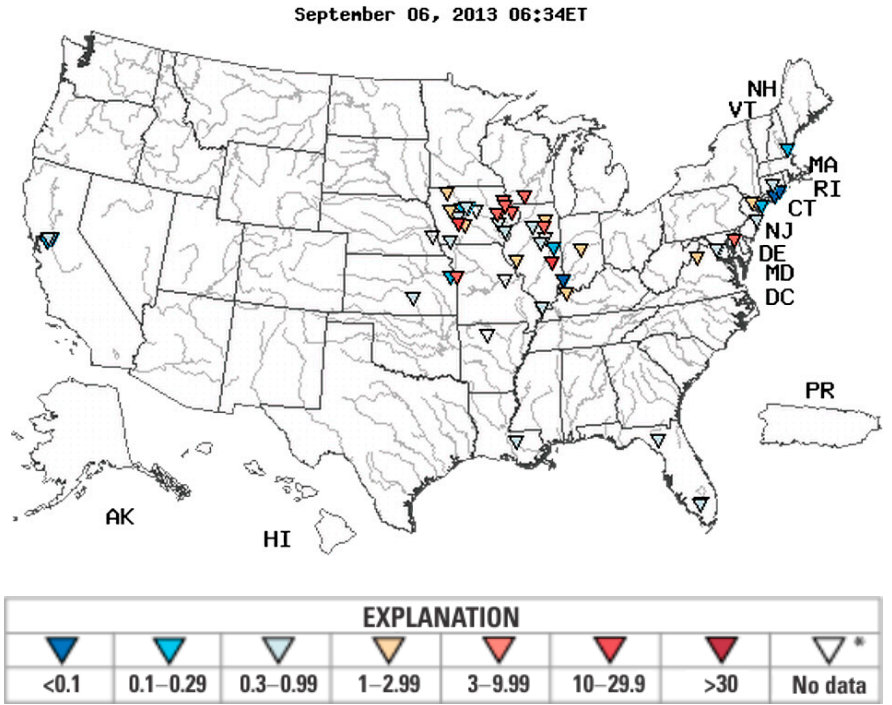

$\boldsymbol{B}$

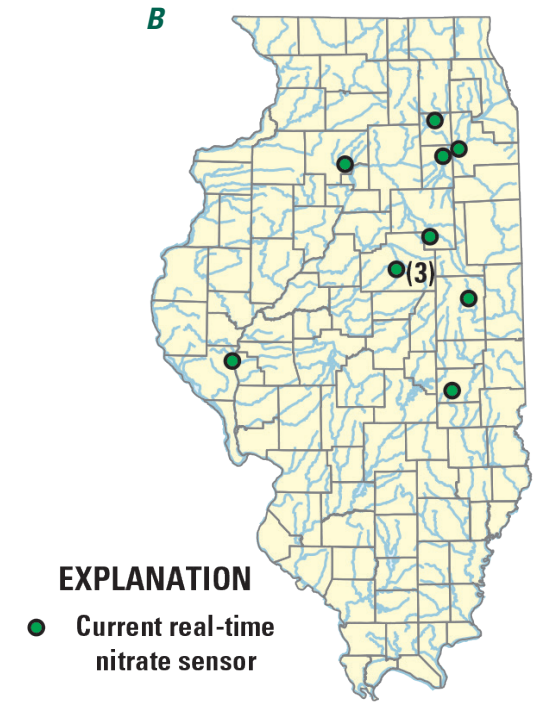

Figure 1. Real-time continuous nitrate monitoring has been implemented in the Midwest. Nitrate concentrations (mg/L) are shown with colored symbols for September 5, $2013(A)$. There are eleven surface-water locations in Illinois with real-time continuous nitrate data collected in $2013(B)$.

\section{What are some applications of continuous nitrate monitoring?}

Continuous data more accurately characterize those sites where water quality is highly variable over short time scales. Sampling seasonally or monthly does not capture the variability of nitrate in riverine environments (fig. 3). Urban areas can have highly variable stream water quality because of the multitude of nitrogen sources in an urban stream and the "flashy" discharge. Agricultural areas, especially those with tile drains that act as conduits for chemicals applied at the land surface, also can have highly variable nitrate concentrations over short time scales during precipitation events or droughts.

Continuous nitrate sensors in the

Midwest can be used to answer scientific questions such as

- What is the effect of green infrastructure on nitrate concentration?

- How do nitrate concentrations change in receiving waters during and after the construction of wastewater facilities?

- What are the daily changes in nitrate concentration that might affect water supplies?

- Can upstream nitrate sensors help forecast when drinking water intakes or near-stream groundwater wells will be impacted by high nitrate concentration?

- How have changes in agricultural practices changed the nitrate concentration and load in streams?
Continuous nitrate data have begun to answer some of these and other questions about the transport of nitrate in streams. Initial studies in Illinois found that nitrate concentrations decrease with precipitation events and then gradually come back up to initial concentrations (fig. 4). However, the total amount of nitrogen moved during storm events (or load) increases. This has implications for when nitrate treatment is needed at drinking water intakes or when nitrate concentrations may disrupt ecosystems during storm events. The calculation of continuous nitrogen loads from continuous nitrate data and discharge can help assess the effectiveness of best-management practices (BMPs). Impaired sites, such as those with factors affecting total maximum daily loads (TMDLs) or sites that drain to ecologically and economically important water bodies, may use water-management strategies more effectively during critical times identified by continuous water-quality monitoring.

Other types of continuous sensors or combinations of sensors will aid in the understanding of the effects of floods and droughts on algal growth and on transport of nitrate, chloride, and other constituents of concern. Many water-quality challenges are complex and water managers can benefit from data characterizing a suite of parameters to answer questions of constituent sources, timing, and management (Pellerin and others, 2012). Combining observations from optical sensors, physical parameters (discharge or temperature), and other sensor measurements (turbidity and specific conductance) at high temporal resolution will create opportunities to evaluate questions related to nitrate or other constituents of concern.

\section{References}

Alexander, R.B., Smith, R.A., Schwarz, G.E., Boyer, E.W., Nolan, J.V., and Brakebill, J.W., 2008, Differences in phosphorus and nitrogen delivery to the Gulf of Mexico from the Mississippi River Basin: Environmental Science and Technology, v. 42, no. 3, p. 822-830, http://water.usgs.gov/nawqa/sparrow/ gulf_findings/ES\&T_states.pdf.

Dubrovsky, N.M., Burow, K.R., Clark, G.M., Gronberg, J.M., Hamilton P.A., Hitt, K.J., Mueller, D.K., Munn, M.D., Nolan, B.T., Puckett, L.J., Rupert, M.G., Short, T.M., Spahr, N.E., Sprague, L.A., and Wilber, W.G., 2010, The quality of our Nation's waters - Nutrients in the Nation's streams and groundwater, 1992-2004: U.S. Geological Survey Circular 1350, 174 p.

Pellerin, B.A., Bergamaschi, B.A., and Horsburgh, J.S., 2012, In situ optical water-quality sensor networks - Workshop summary report: U.S. Geological Survey Open-File Report 2012-1044, $13 \mathrm{p}$.

Pellerin, B.A., Bergamaschi, B.A., Downing, B.D., Saraceno, J.F., Garrett, J.D., and Olsen, L.D., 2013, Optical techniques for the determination of nitrate in environmental waters - Guidelines for instrument selection, operation, deployment, maintenance, quality assurance, and data reporting: U.S. Geological Survey Techniques and Methods 1-D5, $37 \mathrm{p}$. 
Table 1. Real-time monitoring of nitrate at eleven sites provides information on continuously changing nitrate concentrations (as $\mathrm{N}$ in milligrams per liter) in Illinois (accessed January 29, 2013, at http://il.water.usgs.gov/.

[IL, Illinois; NA, not applicable]

\begin{tabular}{|cllclcc}
\hline Site & \multicolumn{1}{c}{ Site name } & \multicolumn{1}{c}{ County } & $\begin{array}{c}\text { Basin size } \\
\text { (square } \\
\text { miles) }\end{array}$ & $\begin{array}{c}\text { Other } \\
\text { continuous } \\
\text { water-quality } \\
\text { parameters }\end{array}$ & $\begin{array}{c}\text { Continuity } \\
\text { of } \\
\text { record }\end{array}$ \\
\hline 03336890 & Spoon River near St. Joseph, IL & Coles & 27.7 & No & Seasonal \\
\hline 03343820 & Kickapoo Creek at 1320E Road nr Charleston, IL & Champaign & 40.7 & No & Seasonal \\
\hline 05543010 & Illinois River at Seneca, IL & La Salle & 8,215 & Yes & Yearly \\
\hline 05551580 & Fox River at Yorkville, IL & Kendall & 1,804 & Yes & Seasonal \\
\hline 05554300 & Indian Creek near Fairbury, IL & Livingston & 67.5 & Yes & Seasonal \\
\hline 05557500 & East Bureau Creek near Bureau, IL & Bureau & 99 & No & Seasonal \\
\hline 05579610 & Kickapoo Creek at 2100E Road near Bloomington, IL & McLean & 7.3 & No & Seasonal \\
\hline 05579620 & Kickapoo Creek Tributary near Bloomington, IL & McLean & 3.8 & No & Seasonal \\
\hline 05579630 & Kickapoo Creek near Bloomington, IL & McLean & 14.8 & Yes & Seasonal \\
\hline 05586300 & Illinois River at Florence, IL [Two-sensor comparison trial] & Pike & 26,870 & Yes & Yearly \\
\hline 411958088280101 & Hanson Gravel Pit at Culvert near Morris, IL & Grundy & NA & Yes & Yearly \\
\hline
\end{tabular}

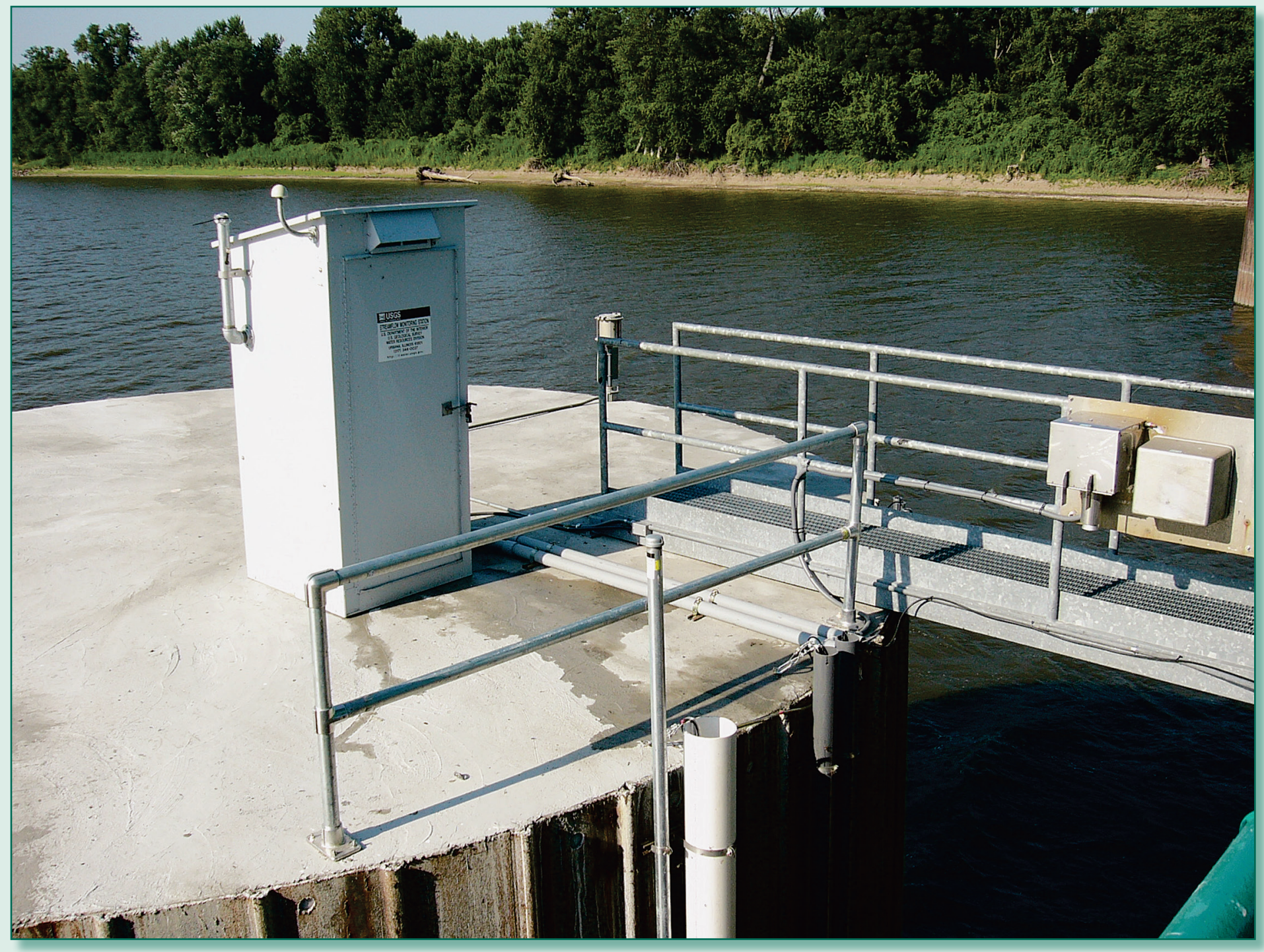

Figure 2. The U.S. Geological Survey gage house at Florence, Illinois, has instrumentation for collecting continuous nitrate concentrations with two different sensors, along with other sensors such as pH, temperature, dissolved oxygen, and specific conductance. This is a large watershed, over 26,000 square miles. Photograph by Nicholas Siudyla, U.S. Geological Survey. 


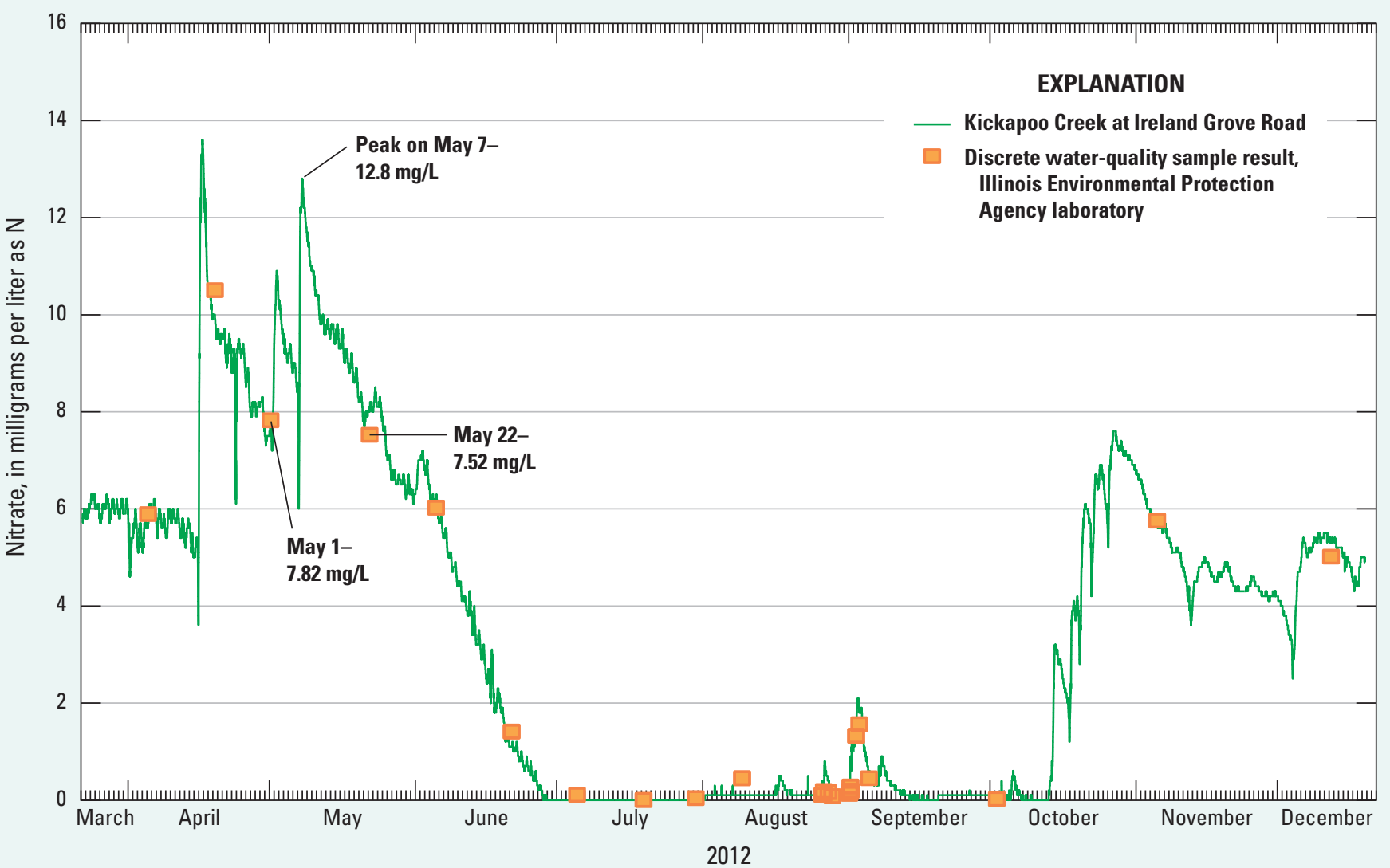

Figure 3. Continuous nitrate monitoring captures spikes in nitrate concentration that would not be evident by periodic laboratory samples. The graph of continuous nitrate concentration from Kickapoo Creek at Ireland Grove Road near Bloomington, Illinois, shows the relation between discrete water-quality samples and continuous data. The continuous data pick up peaks in nitrate concentrations that are not evident in the discrete samples. The peak of 12.8 milligrams per liter (mg/L) as $\mathrm{N}$ between a discrete sample collected on May 1, $2012(7.82 \mathrm{mg} / \mathrm{L})$, and May 22, $2012(7.52 \mathrm{mg} / \mathrm{L})$, would have been missed without the continuous data collection. When nitrate is a concern in drinking water or the accurate calculation of load is needed, the identification of the peak concentration is important for managing the water quality.

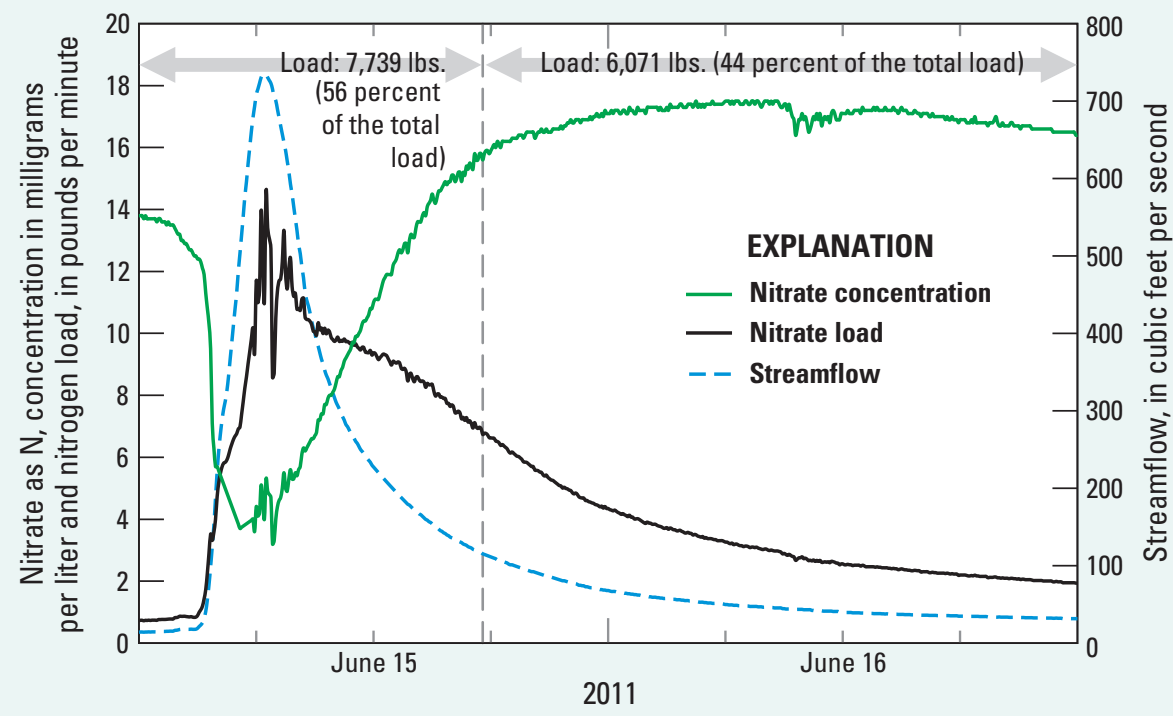

Figure 4. Continuous nitrate concentrations can lead to better understanding of nitrate transport during storm events. This example from Kickapoo Creek at Ireland Grove Road near Bloomington, Illinois, shows the inverse relation between streamflow and nitrate concentration, and the spike in the nitrate load (mass of nitrate during a given time in pounds per minute $(\mathrm{lb} / \mathrm{min}))$ to the stream during the storm event. Based on continuous nitrate and discharge measurements, more than half of the event nitrate load occurred within 15 hours from the initial storm event on June 15, 2011.

Any use of trade, firm, or product names is for descriptive purposes only and does not imply endorsement by the U.S. Government.

By Kelly L. Warner, Paul J. Terrio, Timothy D. Straub, Don Roseboom, and Gary P. Johnson

http://il.water.usgs.gov
For more information contact:

Director, Illinois Water Science Center

U.S. Geological Survey

1021 W. University Ave.

Urbana, IL 61801
ISSN 2327-6916 (print) ISSN 2327-6932 (online) http://doi.dx.org/10.3133/fs20133109 